\title{
ŠTO RODITELJI IMAJU PRAVO ZNATI O DJEČJIM VRŠNJAČKIM ODNOSIMA - MIŠLJENJE ADOLESCENATA I NJIHOVIH MAJKI
}

\author{
Zora Raboteg-Šarić \\ Institut društvenih znanosti Ivo Pilar \\ Marulićev trg 19, 10000 Zagreb \\ zora.raboteg-saric@pilar.hr \\ Ivana Zovak \\ Nastavni zavod za javno zdravstvo Brodsko-posavske županije \\ Služba za zaštitu mentalnog zdravlja, prevenciju i izvanbolničko liječenje ovisnosti \\ Vladimira Nazora 2a, 35000 Slavonski Brod \\ ivanazovak87@gmail.com
}

\begin{abstract}
Sažetak
Cilj istraživanja bio je ispitati stavove adolescenata i njihovih majki o tome što roditelji imaju pravo znati o svojoj djeci te razlike u stavovima roditelja i djece u odnosu na spol i dob adolescenata. Uzorak je obuhvaćao 188 srednjoškolaca (94 djevojke i 94 mladića) prosječne dobi od 16,6 godina i njihove majke $(\mathrm{N}=188)$. Primijenjena je hrvatska verzija Upitnika roditeljskog prava na informacije o djeci (Right to Know Inventory, Krein i Brown, 2004), kojim se mjere stavovi prema legitimnosti roditeljskog autoriteta u odnosu na četiri domene vršnjačkih odnosa adolescenata: aktivnosti s prijateljima, značajke odnosa, negativne karakteristike vršnjaka i pozitivne karakteristike vršnjaka. Rezultati su pokazali da majke općenito procjenjuju svoje pravo na znanje o djeci i njihovim aktivnostima većim nego što im to pravo daju adolescenti. Dobivene su značajne razlike između rezultata majki i djece na svim skalama Upitnika roditeljskog prava na informacije o djeci, osim za pozitivne karakteristike vršnjaka. Složene analize varijance pokazale su značajan efekt spola adolescenata na njihove stavove o roditeljskom pravu na informacije o djeci, kao i značajan efekt spola djeteta na stavove majki. U obje analize učinci dobi djeteta te interakcije spola i dobi nisu značajni. Djevojke, u usporedbi s mladićima, procjenjuju značajno većim roditeljsko pravo na informacije o djeci u svim područjima, osim za pozitivne karakteristike vršnjaka. Majke koje imaju kćer smatraju da imaju značajno veće pravo na informacije o aktivnostima djece s prijateljima i značajkama njihovih odnosa s vršnjacima nego majke sinova. Rezultati se razmatraju u odnosu na istraživanja o legitimnosti roditeljskog autoriteta u različitim socijalnim domenama i istraživanja o adolescentskom samootkrivanju.
\end{abstract}

Ključne riječi: adolescenti, autonomija, odnosi s vršnjacima, roditeljsko pravo na informacije 


\section{UVOD}

Adolescencija je razdoblje koje postavlja nove zahtjeve i izazove u svakodnevnoj komunikaciji djece i roditelja. Postizanje autonomije jedan je od važnijih razvojnih zadataka $u$ adolescenciji, a ovaj proces je uspješniji ako se odvija u kontekstu bliskih i podržavajućih odnosa između adolescenata i njihovih roditelja (Grotevant i Cooper, 1988). Konstrukt autonomije uključuje ponašajne, emocionalne i kognitivne aspekte. Ponašajna autonomija odnosi se na pokazivanje neovisnog funkcioniranja koje uključuje samostalno odlučivanje i regulaciju vlastitog ponašanja. Emocionalna autonomija podrazumijeva odbacivanje dječje ovisnosti o roditeljima, deidealizaciju i zrelije poimanje roditelja te uspostavljanje novih odnosa s njima. Kognitivna autonomija uključuje subjektivni doživljaj kontrole nad vlastitim životom, osjećaje samopouzdanja te prosuđivanje i odlučivanje temeljeno na osobnim načelima, a ne na očekivanjima drugih ljudi (Goossens, 2006).

U adolescenciji prijateljski odnosi postaju kvalitetniji i povećava se važnost podrške prijatelja (Hartup i Stevens, 1977), a adolescenti provode sve više vremena s vršnjacima u školskom i izvanškolskom okruženju, dok se vrijeme provedeno s obitelji smanjuje (Larson, Richards, Moneta, Holmbeck i Duckett, 1996). Nedostatak informacija o aktivnostima adolescenata kod roditelja može izazvati osjećaj gubitka kontrole i nadzora na koji su navikli dok je njihovo dijete bilo mlađe. U ranijim istraživanjima roditeljski nadzor je operacionaliziran kao dječja percepcija roditeljskog poznavanja njihovih svakodnevnih aktivnosti, društva i načina provođenja slobodnog vremena (Brown, Mounts, Lamborn i Steinberg, 1993), a istraživanja roditeljskih odgojnih postupaka dosljedno pokazuju da je slabiji nadzor povezan s problematičnim ponašanjem i zlouporabom sredstava ovisnosti kod adolescenata, dok je bolji nadzor povezan $\mathrm{s}$ indikatorima njihove pozitivne prilagodbe (Raboteg-Šarić, Franc i Brajša-Žganec, 2004). Stattin i Kerr (2000) pružili su novi uvid u objašnjenje nalaza ranijih istraživanja smatrajući da konstrukt roditeljskog nadzora nije adekvatno operacionaliziran. Naime, $u$ velikom broju istraživanja mjeri se roditeljsko znanje o svakodnevnim aktivnostima i prijateljima adolescenata, a ne stvarno roditeljsko ponašanje. Roditelji mogu saznati informacije o djeci na različite načine: tako što im djeca svojevoljno to kažu, traženjem informacija kroz razgovor s djecom i prikupljanjem informacija od drugih osoba (prijatelji, učitelji, drugi roditelji) te kontrolirajući djecu postavljanjem pravila i granica ponašanja $i$ praćenjem pridržavaju li se djeca dogovorenih pravila. Rezultati longitudinalnog istraživanja s velikim uzorkom švedskih adolescenata pokazali su, na temelju procjena djece i roditelja, da roditeljsko znanje o djeci u najvećoj mjeri ovisi o voljnom, slobodnom samootkrivanju adolescenata, a ne o roditeljskim postupcima kontrole i traženja informacija. Uz to, roditeljsko znanje i samootkrivanje adolescenata $u$ većoj su mjeri bili povezani s kasnijim internaliziranim i eksternaliziranim problemima adolescenata nego ponašanja roditelja koja uključuju aktivno traženje informacija i nadzor djece (Stattin, Kerr i Tilton-Weaver, 2010). Rezultati ovih istraživanja u osnovi su u skladu s nalazima ranijih istraživanja o zaštitnom djelovanju 
roditeljskog poznavanja svakodnevnih aktivnosti djece na prilagodbu adolescenata. Međutim, bolja operacionalizacija konstrukta roditeljskog nadzora pokazala je da uzroke ove povezanosti treba tražiti u slobodnom samootkrivanju adolescenata. U novije vrijeme sve se više pozornosti i važnosti pridaje samim adolescentima kao aktivnim sudionicima odnosa roditelj-dijete te njihovim utjecajima na proces odvajanja i osamostaljivanja od roditelja (Tokić, 2008).

Sukobi između djece i roditelja pojavljuju se češće kada se njihova percepcija ponašajne autonomije adolescenata razlikuje, primjerice, kada odlučuju o tome koja je odgovarajuća dob za pojedine aktivnosti. Adolescenti smatraju da bi trebali imati autonomiju u ranijoj dobi nego što to misle njihovi roditelji (Daddis i Smetana, 2005). Selektivno otkrivanje informacija o sebi jedan je od načina uspostave neovisnosti o roditeljima. Birajući koliko će se često i o čemu povjeravati roditeljima adolescenti reguliraju u kojoj mjeri žele dopustiti roditeljima pristup u određena područja svoga života (Brown, Bakken, Nguyen i Von Bank, 2007; Finkenauer, Frijns, Engels i Kerkhof, 2005). Kvalitativne analize komunikacije između djece i roditelja pokazuju da adolescenti upotrebljavaju različite strategije upravljanja informacijama koje će prenijeti roditeljima: potpuno samootkrivanje, djelomično samootkrivanje (npr. govore roditeljima istinu, ali izostavljaju određene detalje), izbjegavanje (određenih tema ili roditelja ako pokazuju preveliko zanimanje za takve teme, čekanje dok roditelji ne pitaju) i laganje roditeljima (Bakken i Brown, 2010). Istraživanja stavova adolescenata o legitimnosti roditeljskog autoriteta i razloga samootkrivanja adolescenata najčešće upotrebljavaju klasifikaciju temeljenu na modelu specifičnog moralnog i socijalnog razvoja u odnosu na različite domene društvenog života koji razlikuje tri područja: moralnost (pitanja pravednosti, dobrobiti i prava drugih ljudi), društvene konvencije (kontekstualno relativne norme, društveno dogovorena pravila) i osobno područje koje se odnosi samo na pojedinca. U predadolescentskoj dobi djeca osobna pitanja doživljavaju manje štetnima ili manje pogrešnima od moralnih i socijalnih pitanja jer su takva ponašanja privatna i ne utječu na druge (Nucci, 2001). Istraživanja u okviru teorije socijalnih domena roditeljskog autoriteta pokazuju da roditelji i adolescenti imaju različita stajališta o tome tko ima veću nadležnost $u$ određenim područjima života djece (Smetana $i$ Metzger, 2008). Adolescenti i roditelji smatraju roditeljsku nadležnost legitimnom kada se radi o moralnim pitanjima i proizvoljnim konvencionalnim aktivnostima (npr. pristojno ponašanje) te $u$ domeni razboritosti (sigurnosti), poput sudjelovanja djece u rizičnim aktivnostima. Roditelji i djeca donekle se slažu da bi adolescenti trebali biti nadležni za osobna pitanja koja uključuju privatnost, kontrolu nad tijelom, izbor slobodnih aktivnost i prijatelja, ali djeca smatraju da imaju veću nadležnost $u$ ovom području nego što im to roditelji dopuštaju. Razlike u stavovima roditelja i djece često dolaze do izražaja i u odnosu na višefacetna pitanja koja uključuju preklapanje različitih domena (npr. druženje s nepoželjnim prijateljima, seksualna intimnost, gledanje nasilnih filmova). Roditelji postavljaju pravila u tom području $\mathrm{i}$ ističu konvencionalne elemente i sigurnost djece, dok adolescenti teže postizanju 
osobne autonomije i žele uključiti više takvih aktivnosti u područje osobnih pitanja i imati nad njima nadležnost (Darling, Cumsille, Caldwell i Dowdy, 2006; Smetana i Metzger, 2008). Kako postaju stariji, adolescenti smatraju da roditelji imaju manje pravo uvida u osobna područja njihova života, kao što su aktivnosti s prijateljima i odnosi s vršnjacima. Roditelji određuju više pravila u području osobnih pitanja djevojkama nego mladićima (Smetana i Asquith, 1994). Djevojke se više otkrivaju majci (Lacković-Grgin, Penezić i Žutelija, 2001) i više otkrivaju informacije o osobnim pitanjima nego mladići (Pećnik i Tokić, 2011; Smetana, Metzger, Gettman i Campione-Barr, 2006).

Istraživanja su uglavnom ispitivala adolescentsko samootkrivanje i prešućivanje informacija u domeni prijateljstva i aktivnosti u slobodnom vremenu. Malo je istraživanja o tome kako adolescenti skrivaju informacije o rizičnim ponašanjima, poput konzumiranja alkohola i droga, druženja s devijantnim vršnjacima ili nerazborite vožnje automobila (Smetana i Rote, 2015). Kada mladi vjeruju da roditelji imaju u određenim područjima legitiman autoritet, oni se više samootkrivaju i osjećaju snažniju obvezu da podijele takve informacije s roditeljima. Primjerice, adolescenti smatraju da je njihova dužnost poštovati roditeljska pravila kada se radi o pitanjima njihove sigurnosti. Međutim, kada se radi o osobnim pitanjima, oni češće izbjegavaju rasprave s roditeljima ili se samo djelomično otkrivaju (Darling i sur., 2006; Smetana i sur., 2006), a također često skrivaju ove informacije iz pragmatičnih razloga, tj. da bi izbjegli roditeljsko neodobravanje i eventualne posljedice (Bakken i Brown, 2010).

$\mathrm{Na}$ temelju dosadašnjih istraživanja može se zaključiti kako adolescenti koji svojevoljno otkrivaju informacije roditeljima vjeruju da njihovi roditelji imaju pravo znati takve informacije. Većina istraživanja je, slijedeći pristup u okviru teorije socijalnih domena, upotrebljavala klasifikaciju pitanja oko kojih se vode rasprave između adolescenata i roditelja u šira područja društvenog života adolescenata koja ne diferenciraju dobro njihove odnose s vršnjacima (Bakken i Brown, 2010; Chan, Brown i Von Bank, 2015). Brown i suradnici (2007) smatraju kako razumijevanje odluka adolescenata o samootkrivanju informacija o vršnjacima zahtijeva temeljitiju procjenu područja vršnjačkih odnosa. Krein i Brown (2004) su, na temelju kvalitativnih istraživanja s adolescentima i njihovih procjena o tome koliko roditelji imaju prava na informacije o djeci, identificirali četiri domene aktivnosti i odnosa adolescenata s vršnjacima: aktivnosti s prijateljima, značajke odnosa s vršnjacima, pozitivne karakteristike vršnjaka i negativne karakteristike vršnjaka. Chan, Brown i Von Bank (2015) su u svom istraživanju dobili značajne visoke pozitivne korelacije između stavova adolescenata o legitimnosti roditeljskog autoriteta u navedenim domenama odnosa s vršnjacima i njihova slobodnog samootkrivanja informacija koje se odnose na ta područja. Uz to, stavovi adolescenata o tome što roditelji imaju pravo znati o određenim domenama njihovih odnosa s prijateljima i vršnjacima imali su medijatornu ulogu između nekih značajnih prediktora samootkrivanja adolescenata, posebice kvalitete odnosa između djece i roditelja i antisocijalnog ponašanja ado- 
lescenata, i stvarnog samootkrivanja roditeljima u različitim područjima interakcija s vršnjacima. Ovo istraživanje posvećeno je početnoj fazi odlučivanja adolescenata o kojim područjima odnosa s prijateljima i vršnjacima će se povjeravati roditeljima i time im omogućiti da znaju više o njihovim svakodnevnim aktivnostima.

Cilj istraživanja bio je ispitati specifičnosti i razlike u stavovima adolescenata i njihovih majki o tome što roditelji imaju pravo znati u odnosu na različite domene interakcija i iskustava adolescenata s vršnjacima. Dodatni cilj bio je provjeriti razlikuju li se stavovi djece i majki u odnosu na legitimnost roditeljskog autoriteta u navedenim područjima s obzirom na spol i dob adolescenata.

\section{METODA}

\section{Sudionici}

U istraživanju su sudjelovali srednjoškolci u dobi od 15 do 19 godina iz Slavonskog Broda i njihove majke ( $\mathrm{N}=376)$. U početku je kontaktirano 239 učenika, a konačni uzorak činilo je 188 učenika (94 djevojke i 94 mladića) čije su majke ispunile upitnik i 188 majki. U uzorku je podjednak broj učenika prvih (31,4\%), drugih (34\%) i trećih razreda (34,6\%), a među njima je $41.5 \%$ gimnazijalaca i $58.5 \%$ učenika stručnih srednjih škola (medicinske i tehničke). Prosječna dob djece je 16.63 godine $(\mathrm{SD}=0,96)$, a prosječna dob njihovih majki je 43.88 godina $(\mathrm{SD}=4,79)$. Većina majki ima završenu srednju školu $(72,5 \%), 14.1 \%$ majki ima završenu višu školu ili fakultet, a 13,5\% majki je završilo osnovnu školu. S obzirom na bračni status, uzorak u najvećoj mjeri uključuje udane majke (91,3\%) te $8.7 \%$ samohranih majki (rastavljene, neudane i udovice). Najviše majki ima dvoje (44,3\%) ili troje $(35,7 \%)$ djece, $15,6 \%$ majki ima četvoro ili više djece, a 4,3\% majki ima jedno dijete.

\section{Instrumenti}

Upitnik roditeljskog prava na informacije o djeci (Right to Know Inventory, Krein i Brown, 2004). Ovaj upitnik sadrži 31 česticu čiji je sadržaj formuliran na temelju fokusnih grupa i intervjua s adolescentima u preliminarnim istraživanjima. Čestice opisuju aktivnosti i odnose adolescenata s prijateljima i vršnjacima te opise njihova ponašanja. Zadatak sudionika je da na ljestvici Likertova tipa označe stupanj slaganja sa sadržajem čestice od 1 ("sigurno ne") do 5 ("sigurno da"). Verzije upitnika za adolescente i roditelje uključuju iste čestice, a razlikuju se samo prema pitanju koje prethodi procjenama sadržaja čestica. Adolescenti na sve tvrdnje odgovaraju s obzirom na pitanje: "Imaju li tvoji roditelji pravo znati...?", a roditelji na pitanje: "Kao roditelj, imate li pravo znati o svom djetetu...?”. Na temelju faktorske 
analize rezultata 231 učenika u dobi od 12 do 18 godina formirane su četiri skale koje mjere različite domene stavova adolescenata o pravu roditelja na informacije o djeci: aktivnosti s prijateljima, značajke odnosa s vršnjacima, pozitivne karakteristike vršnjaka i negativne karakteristike vršnjaka. Vrijednosti Cronbachovih alfa koeficijenata za pojedine skale kreću se u rasponu od 0,81 do 0,90 , a test-retest koeficijenata pouzdanosti u istraživanju provedenom nakon pet tjedana od 0,75 do 0,84 (Krein, 2003).

Upitnik roditeljskog prava na informacije o djeci prvi put je primijenjen u uzorku adolescenata i njihovih majki u ovom istraživanju te je nakon prijevoda na hrvatski jezik i povratnog prijevoda najprije provjerena faktorska struktura hrvatske verzije ovog upitnika. Provedene su analize glavnih komponenata uz varimax rotaciju posebno za rezultate adolescenata i za rezultate majki. Zadržane su čestice koje imaju faktorska zasićenja veća od 0,40 na pripadajućem faktoru. U početnoj analizi u uzorku adolescenata tri čestice su imale značajna zasićenja na nekom drugom, a ne pripadajućem faktoru, a u uzorku majki sukcesivnim komponentnim analizama izostavljeno je još pet čestica koje nisu imale značajne saturacije ni na jednom faktoru ili su pokazale značajno zasićenje samo na nepripadajućem faktoru. Iz konačne analize izostavljeno je osam čestica: po dvije iz skala aktivnosti s vršnjacima i negativnih karakteristika vršnjaka iz originalnog upitnika, tri čestice koje mjere odnose s vršnjacima te jedna koja opisuje pozitivne karakteristike vršnjaka. Nakon toga provjerena je faktorska struktura skraćenog upitnika od 23 čestice u uzorku adolescenata i u uzorku njihovih majki. Analizom glavnih komponenata izdvojilo se pet faktora sa svojstvenom vrijednošću većom od jedan u oba uzorka, a na temelju scree testa ekstrahirana su četiri faktora koji objašnjavaju 56,07\% ukupne varijance u uzorku učenika i 54,25\% varijance u uzorku majki. Adaptirana verzija upitnika pokazala je jasnu faktorsku strukturu koja odgovara originalnom upitniku. U uzorku adolescenata sve čestice imaju zasićenja veća od 0.40 samo na pripadajućem faktoru, dok u uzorku majki tri čestice koje opisuju karakteristike vršnjaka imaju značajna, ali manja zasićenja i na faktoru odnosa s vršnjacima. Tuckerovi koeficijenti kongruencije pokazali su da su faktori odnosa s vršnjacima (CC $=0,96)$, pozitivnih $(\mathrm{CC}=0,98)$ i negativnih $(\mathrm{CC}=0,95)$ karakteristika vršnjaka gotovo identični u uzorku adolescenata i majki, a za faktor aktivnosti s prijateljima $(\mathrm{CC}=0,88)$ također je utvrđeno dobro slaganje u oba uzorka. Na temelju faktorskih analiza formirane su četiri subskale hrvatske verzije Upitnika o roditeljskom pravu na informacije o djeci.

Skala aktivnosti s prijateljima (4 čestice) uključuje tvrdnje koje se odnose na roditeljsko pravo na znanje o tome tko su prijatelji njihove djece, što rade dok su s njima, gdje se druže i tko je još s njima kada su s prijateljima. Skala odnosa s vršnjacima (5 čestica) uključuje dvije čestice koje opisuju ljutnju i svađu s prijateljima te tri tvrdnje koje opisuju romantične odnose (sviđanje, svađa, prekid). Skala pozitivnih karakteristika vršnjaka (7 čestica) sadrži tvrdnje koje opisuju pozitivna 
obilježja prijatelja (npr. uključenost u izvanškolske aktivnosti, pomažu li puno kod kuće) i grupe vršnjaka (npr. imaju li dobre ocjene). Skala negativnih karakteristika vršnjaka (7 čestica) mjeri roditeljsko pravo na informacije o rizičnim ponašanjima prijatelja djece (npr. konzumiranje droge i alkohola, problemi sa zakonom, rade li nešto što roditelji ne odobravaju) i negativnim obilježjima vršnjaka u školi (uzimaju li droge i imaju li problema sa zakonom). Item analize (Cronbachovi alpha koeficijenti) pokazale su zadovoljavajuću pouzdanost skala odnosa s vršnjacima $\left(\alpha_{\text {dieca }}=\right.$ $\left.0,78, \alpha_{\text {majke }}=0,80\right)$, pozitivnih $\left(\alpha_{\text {djeca }}=0,86, \alpha_{\text {majke }}=0,79\right)$ i negativnih $\left(\alpha_{\text {djeca }}=0,82\right.$, $\left.\alpha_{\text {maike }}=0,79\right)$ karakteristika vršnjaka te nešto nižu pouzdanost Skale aktivnosti s prijateljima $\left(\alpha_{\text {djeca }}=0,66, \alpha_{\text {majke }}=0,68\right)$ u uzorku djece i majki. U obradi rezultata vrijednosti koje nedostaju na skalama roditeljskog prava na informacije o djeci (manje od 5\% procjena na pojedinim česticama) zamijenjene su prosječnim vrijednostima. Ukupan rezultat na svakoj skali izražen je kao aritmetička sredina svih procjena na pripadajućim česticama skale.

Sociodemografski podaci. Uz stavove o roditeljskom pravu na informacije o djeci prikupljeni su i osnovni sociodemografski podaci o sudionicima istraživanja. Adolescenti su odgovarali na pitanja o spolu, dobi, razredu i školi koju pohađaju, a majke o svom stupnju obrazovanja, bračnom statusu i broju djece u obitelji.

\section{Postupak}

Istraživanje se provodilo unutar pojedinih razrednih odjela tijekom školskog sata, uz prethodno odobrenje ravnatelja škola. Učenicima je objašnjena svrha istraživanja, obaviješteni su da će anonimno ispunjavati upitnik i dana im je mogućnost da slobodno odluče o svom sudjelovanju. Po završetku ispunjavanja Upitnika roditeljskog prava na informacije o djeci (verzija za adolescente) upitnici učenika su odmah prikupljeni, a učenici su naknadno trebali donijeti u školu ispunjene upitnike njihovih majki. Učenici su dobili zatvorene kuverte u kojima se nalazilo pismo roditeljima koje objašnjava svrhu i postupak istraživanja te Upitnik o pravu roditelja na informacije o djeci - verzija za roditelje. Majke su dobile uputu da, ako imaju više djece, upitnik ispunjavaju u odnosu na ono dijete koje je sudjelovalo u istraživanju. Na svakom učeničkom upitniku bila je upisana ista šifra kao i na upitniku za njihove majke kako bi se na taj način kasnije upitnici mogli upariti. U ovom istraživanju zbog ograničenih mogućnosti nismo izravno ispitivali majke te nismo mogli kontrolirati jesu li sva djeca vratila ispunjene upitnike. Anonimnim ispitivanjem nastojali smo pridobiti što veći broj majki za suradnju, a njihov odaziv bio je relativno velik. Od 239 poslanih upitnika majkama prikupljeno je njih 188 ili 78.7\%. Učenici čije su majke ispunile upitnik $(\mathrm{N}=188)$ i učenici čije majke nisu sudjelovale u istraživanju $(\mathrm{N}=51)$ nisu se razlikovali s obzirom na spol $\left(\chi^{2}=1,25, d f=1, p>0,05\right)$ i $\operatorname{dob}(t(237)=0,36, p>0,05)$. 


\section{REZULTATI}

Usporedba stavova adolescenata i majki o roditeljskom pravu na informacije o djeci

Usporedbom prosječnih rezultata majki i djece (Slika 1) na skalama stavova prema roditeljskom pravu na informacije o djeci može se uočiti da majke u svim područjima pridaju sebi veće pravo nego što im to priznaju djeca. Prema mišljenju majki, roditelji imaju najviše prava znati o aktivnostima adolescenata s prijateljima. Prosječna procjena majki odgovara opisu na skali između "vjerojatno da" (4) i "sigurno da" (5). Iako se mišljenje majki i djece iz istih obitelji o ovom pitanju razlikuje $\left(\mathrm{M}_{\mathrm{M}-\mathrm{D}}=0,61, \mathrm{SD}_{\mathrm{M}-\mathrm{D}}=0,83\right)$, djeca priznaju roditeljima najveću nadležnost u ovom području, a srednje vrijednosti njihovih procjena odgovaraju pozitivnom dijelu skale ( 4 = "vjerojatno da"). Sljedeće područje u kojem majke sebi pridaju veće pravo je poznavanje negativnih karakteristika vršnjaka, ali se tu stavovi majki i njihove djece najviše razlikuju $\left(\mathrm{M}_{\mathrm{M}-\mathrm{D}}=1,27, \mathrm{SD}_{\mathrm{M}-\mathrm{D}}=1,21\right)$ jer adolescenti pridaju najmanje prava roditeljima na takve informacije. Srednje vrijednosti procjena djece kreću se između negativnog $(2=$ "vjerojatno ne") i neutralnog $(3=$ "nisam siguran") dijela skale, dok prosječne procjene majki odgovaraju pozitivnom dijelu skale (4 = "vjerojatno da"). Majke i djeca pokazuju veća neslaganja i u području odnosa djece s vršnjacima $\left(\mathrm{M}_{\mathrm{M}-\mathrm{D}}=0,94, \mathrm{SD}_{\mathrm{M}-\mathrm{D}}=1,10\right)$, pri čemu majke u prosjeku smatraju da vjerojatno imaju nadležnost u ovom području, dok djeca nisu sigurna u ocjeni roditeljske nadležnosti ili pak smatraju da majke vjerojatno nemaju pravo na takve informacije. Majke i djeca najmanje se razlikuju $\left(\mathrm{M}_{\mathrm{M}-\mathrm{D}}=0,15, \mathrm{SD}_{\mathrm{M}-\mathrm{D}}=1,08\right)$

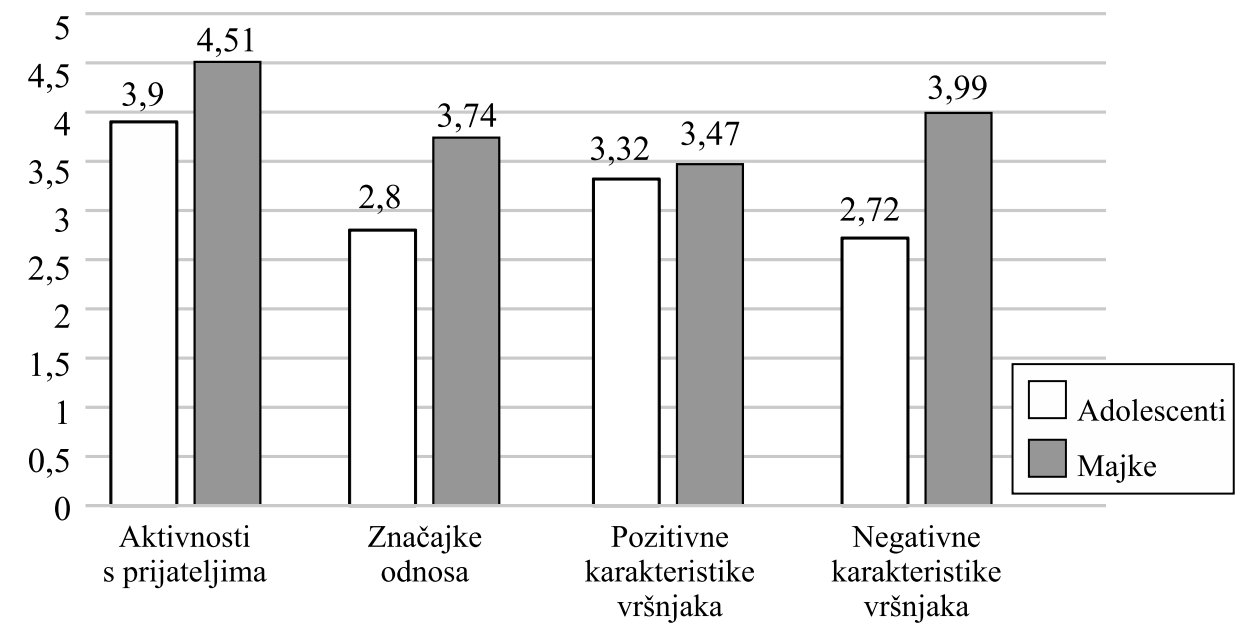

Slika 1. Prosječne vrijednosti rezultata adolescenata $(\mathrm{N}=188)$ i majki $(\mathrm{N}=188)$ na skalama stavova o roditeljskom pravu na informacije o djeci 
Tablica 1. Razlike u stavovima adolescenata i njihovih majki o pravu roditelja na informacije o djeci ( $t$-test za zavisne uzorke)

\begin{tabular}{|c|c|c|c|c|c|c|}
\hline \multirow[b]{2}{*}{ Varijable } & \multicolumn{2}{|c|}{ Djeca $(\mathrm{N}=188)$} & \multicolumn{2}{|c|}{ Majke $(\mathrm{N}=188)$} & \multirow{2}{*}{$t_{(187)}$} & \multirow{2}{*}{$p$} \\
\hline & M & SD & $\mathrm{M}$ & SD & & \\
\hline Aktivnosti s prijateljima & 3,90 & 0,73 & 4,51 & 0,55 & 10,11 & .000 \\
\hline Značajke odnosa s vršnjacima & 2,80 & 0,97 & 3,74 & 0,87 & 11,80 & .000 \\
\hline Pozitivne karakteristike vršnjaka & 3,32 & 0,99 & 3,47 & 0,73 & 1,93 & .055 \\
\hline Negativne karakteristike vršnjaka & 2,72 & 0,95 & 3,99 & 0,86 & 14,40 & .000 \\
\hline
\end{tabular}

u stavovima o roditeljskom pravu na poznavanje pozitivnih karakteristika vršnjaka, a njihove procjene $u$ ovom području kreću se oko neutralnog dijela skale.

Značajnost razlika između prosječnih procjena parova djece i majki iz istih obitelji na skalama Upitnika roditeljskog prava na informacije o djeci ispitana je t-testom za zavisne uzorke (Tablica 1). U određivanju kritične vrijednosti za razinu značajnosti razlika između pojedinih skupina sudionika na svakoj od četiri skale u ovoj i sljedećim analizama primijenjena je Bonferronijeva korekcija s $p=0,05$ na $p=0,0125$.

Rezultati u Tablici 1 pokazuju da se adolescenti i majke statistički značajno razlikuju s obzirom na tri domene stavova o pravu roditelja na informacije o djeci: aktivnosti s prijateljima, značajke odnosa s vršnjacima i negativne karakteristike vršnjaka. Majke smatraju da roditelji u ovim područjima imaju veću nadležnost nego što im to priznaju djeca. Razlike između stavova majki i njihove djece u odnosu na pravo roditelja na informacije o pozitivnim karakteristikama vršnjaka nisu statistički značajne.

Tablica 2. Interkorelacije rezultata adolescenata (iznad dijagonale) i majki (ispod dijagonale) na skalama Upitnika roditeljskog prava na informacije o djeci

\begin{tabular}{lcccc}
\hline Skale & $\begin{array}{c}\text { Aktivnosti s } \\
\text { prijateljima }\end{array}$ & $\begin{array}{c}\text { Značajke } \\
\text { odnosa }\end{array}$ & $\begin{array}{c}\text { Pozitivne } \\
\text { karakteristike } \\
\text { vršnjaka }\end{array}$ & $\begin{array}{c}\text { Negativne } \\
\text { karakteristike } \\
\text { vršnjaka }\end{array}$ \\
\hline Aktivnosti s prijateljima & 1 & $0,39^{* *}$ & $0,25^{* *}$ & $0,42^{* *}$ \\
Značajke odnosa & $0,50^{* *}$ & 1 & $0,33^{* *}$ & $0,44^{* *}$ \\
Pozitivne karakteristike vršnjaka & $0,27^{* *}$ & $0,26^{* *}$ & 1 & $0,17^{*}$ \\
Negativne karakteristike vršnjaka & $0,48^{* *}$ & $0,58^{* *}$ & $0,17^{*}$ & 1 \\
\hline
\end{tabular}

${ }^{*} p \leq 0,05 ; * * p \leq 0,01$ 
Pearsonovi koeficijenti korelacija između rezultata na skalama Upitnika roditeljskog prava na informacije o djeci značajni su u uzorku adolescenata i u uzorku majki. Pritom su korelacije između stavova o legitimnosti roditeljskog autoriteta $u$ području pozitivnih karakteristika vršnjaka i ostalim područjima vršnjačkih odnosa manje u usporedbi s interkorelacijama rezultata na skalama aktivnosti s prijateljima, značajki odnosa s vršnjacima i negativnih karakteristika vršnjaka.

Korelacije između procjena majki i djece na skalama Upitnika roditeljskog prava na informacije o djeci upućuju na njihovo slaganje u tri od četiri domene vršnjačkih odnosa. Dobivene su niske, ali statistički značajne, pozitivne korelacije između procjena majki i djece u području aktivnosti adolescenata s prijateljima $(r=0,19$, $p=0,01)$, značajkama njihovih odnosa s vršnjacima $(r=0,29, p<0,01)$ i pozitivnih karakteristika vršnjaka $(r=0,25, p<0,01)$. Korelacija između stavova majki i djece u odnosu na roditeljsko pravo na informacije o negativnim karakteristikama vršnjaka nije značajna $(r=0,11, p>0,05)$.

Spolne i dobne razlike u stavovima adolescenata o roditeljskom pravu na informacije o djeci

Kako bi se ispitali učinci spola i dobi adolescenata na njihove stavove o pravu roditelja na informacije o djeci, provedena je složena analiza varijance $(2 \times 3 \mathrm{MA}$ NOVA) sa spolom adolescenata (muški, ženski) i razredom koji pohađaju (prvi, drugi i treći) kao nezavisnim varijablama te četiri domene stavova kao zavisnim varijablama. Rezultati su pokazali značajne glavne efekte spola (Wilksova $\lambda=0,84$, $\mathrm{F}(4,179)=8,81$, parcijalni $\left.\eta^{2}=0,16, p=0,000\right)$ i dobi sudionika (Wilksova $\lambda=$ $0,89, \mathrm{~F}(8,358)=2,81$, parcijalni $\left.\eta^{2}=0,06, p=0,005\right)$ na stavove adolescenata, dok interakcija spola i dobi nije značajna (Wilksova $\lambda=0,95, F(8,358)=1,29$, parcijalni $\left.\eta^{2}=0,03, p=0,245\right)$.

Jednosmjerne analize varijance rezultata sudionika različitog spola pokazale su da značajnom efektu spola pridonose skale značajki odnosa, aktivnosti s vršnjacima

Tablica 3. Deskriptivna statistika i rezultati analiza varijance za spolne razlike u stavovima adolescenata $(\mathrm{N}=188)$ o roditeljskom pravu na informacije o djeci

\begin{tabular}{|c|c|c|c|c|c|c|}
\hline \multirow[b]{2}{*}{ Varijable } & \multicolumn{2}{|c|}{ Djevojke $(\mathrm{N}=94)$} & \multicolumn{2}{|c|}{ Mladići $(\mathrm{N}=94)$} & \multirow{2}{*}{$\mathrm{F}_{(1,186)}$} & \multirow{2}{*}{$p$} \\
\hline & M & SD & M & SD & & \\
\hline Aktivnosti s vršnjacima & 4,11 & 0,56 & 3,69 & 0,82 & 17,73 & 0,000 \\
\hline Značajke odnosa & 3,09 & 0,93 & 2,51 & 0,92 & 18,63 & 0,000 \\
\hline Pozitivne karakteristike vršnjaka & 3,29 & 1,08 & 3,34 & 0,89 & 0,09 & 0,761 \\
\hline Negativne karakteristike vršnjaka & 2,96 & 0,95 & 2,49 & 0,89 & 12,20 & 0,001 \\
\hline
\end{tabular}


i negativnih karakteristika vršnjaka. Djevojke u značajno većoj mjeri od mladića smatraju da roditelji imaju pravo na informacije u ovim područjima, dok spolne razlike $\mathrm{u}$ procjeni roditeljskog prava na informacije o pozitivnim karakteristikama vršnjaka nisu značajne (Tablica 3).

Rezultati složene analize varijance pokazali su također značajan efekt dobi sudionika (razreda koji pohađaju) na njihove stavove prema pravu roditelja na znanje o različitim područjima njihova života, a dobne razlike objašnjavaju manji dio varijance zavisnih varijabli $(6 \%)$ nego razlike u stavovima djevojaka i mladića (16\%). Radi interpretacije značajnog glavnog efekta dobi provedene su jednostavne analize varijance za svaku zavisnu varijablu. Razlike između rezultata učenika prvih, drugih i trećih razreda pokazale su se značajnima samo za stavove prema pravu roditelja na informacije o značajkama odnosa djece s vršnjacima $(\mathrm{F}(2,185)=3,38$, $p=0,036$ ), pri čemu učenici trećeg razreda priznaju roditeljima veću nadležnost $\mathrm{u}$ ovom području od učenika prvih razreda (Tukey post-hoc test). Međutim, u ovom slučaju glavni efekt dobi ne zadovoljava kriterij razine značajnosti uz primjenu Bonferronijeve korekcije te se općenito može zaključiti da dobne razlike u stavovima adolescenata o roditeljskom pravu na informacije o djeci nisu značajne.

Razlike u stavovima majki o roditeljskom pravu na informacije o djeci u odnosu na spol i dob djeteta

Multivarijatnom analizom varijance $(2 \times 3$ MANOVA) također su provjeravani učinci spola i dobi adolescenata na stavove majki o roditeljskom pravu na informacije o djeci. Rezultati su pokazali značajan efekt spola djeteta (Wilksova $\lambda=0,91$, $\mathrm{F}(4,179)=4,69$, parcijalni $\eta^{2}=0,10, p=0,000$ ), dok učinci dobi djeteta (Wilksova $\lambda=0,94, \mathrm{~F}(8,358)=1,43$, parcijalni $\left.\eta^{2}=0,03, p=0,183\right)$ i interakcije spola i dobi djeteta (Wilksova $\lambda=0,96, \mathrm{~F}(8,358)=1,00$, parcijalni $\eta^{2}=0,02, p=0,433$ ) na stavove majki nisu značajni.

Tablica 4. Stavovi majki $(\mathrm{N}=188)$ o roditeljskom pravu na informacije o djeci u odnosu na spol djeteta: deskriptivna statistika i rezultati analiza varijance

\begin{tabular}{|c|c|c|c|c|c|c|}
\hline \multirow[b]{2}{*}{ Varijable } & \multicolumn{2}{|c|}{$\begin{array}{l}\text { Majke kćeri } \\
(\mathrm{N}=94)\end{array}$} & \multicolumn{2}{|c|}{$\begin{array}{l}\text { Majke sinova } \\
(\mathrm{N}=94)\end{array}$} & \multirow{2}{*}{$\mathrm{F}_{(1,186)}$} & \multirow{2}{*}{$p$} \\
\hline & M & $\mathrm{SD}$ & M & SD & & \\
\hline Aktivnosti s prijateljima & 4,64 & 0,42 & 4,39 & 0,64 & 10,19 & 0,002 \\
\hline Značajke odnosa & 3,93 & 0,78 & 3,54 & 0,91 & 9,92 & 0,002 \\
\hline Pozitivne karakteristike vršnjaka & 3,46 & 0,70 & 3,48 & 0,77 & 0,02 & 0,885 \\
\hline Negativne karakteristike vršnjaka & 4,04 & 0,82 & 3,94 & 0,91 & 0,66 & 0,419 \\
\hline
\end{tabular}


S obzirom na to da su utvrđene statistički značajne razlike u stavovima majki koje imaju sinove i majki koje imaju kćeri, provedene su jednosmjerne analize varijance za svaku zavisnu varijablu. Rezultati ovih analiza (Tablica 4) pokazali su da majke pridaju roditeljima značajno veću nadležnost u području značajki odnosa djece s vršnjacima i njihovih aktivnosti s prijateljima kada se radi o kćerima nego kada su u pitanju sinovi. Razlike između stavova majki djevojaka i mladića o pravu roditelja na informacije o pozitivnim i negativnim karakteristikama vršnjaka nisu značajne. Na temelju rezultata složenih analiza varijance može se zaključiti da spol djeteta ima značajne učinke na stavove djece i majki i objašnjava veći dio varijance stavova adolescenata (16\%) nego stavova njihovih majki (10\%). Djevojke i njihove majke smatraju da roditelji imaju više prava na informacije o djeci nego mladići i njihove majke. Stavovi adolescenata i majki ne razlikuju se s obzirom na dob djeteta.

\section{RASPRAVA}

U ovom istraživanju ispitivali smo razlike i sličnosti između stavova adolescenata i njihovih majki u odnosu na roditeljsko pravo na informacije o različitim područjima interakcija i odnosa djece s vršnjacima. Prosječne procjene na skalama Upitnika roditeljskog prava na informacije o djeci, koji je primijenjen u ovom istraživanju pokazuju da majke u svim područjima procjenjuju roditeljsku nadležnost legitimnom i većom nego što im to priznaju djeca. Adolescenti općenito smatraju da roditelji imaju pravo znati o njihovim aktivnostima s prijateljima i pozitivnim karakteristikama vršnjaka, dok se prosječne procjene o pravu roditelja na informacije u području značajki odnosa s vršnjacima i negativnih karakteristika vršnjaka kreću između negativnog ("vjerojatno ne") i neutralnog dijela skale ("nisam siguran"). I majke i adolescenti priznaju roditeljima najveću nadležnost u domeni aktivnosti djece s prijateljima. Ovaj nalaz u skladu je s rezultatima istraživanja s američkim adolescentima koje je pokazalo da oni priznaju roditeljima značajno veće pravo na znanje o njihovim aktivnostima s prijateljima nego u ostalim područjima vršnjačkih odnosa (Chan i sur., 2015). Ispitivanje značajnosti razlika između stavova adolescenata i njihovih majki pokazalo je da majke procjenjuju značajno većim pravo roditelja na informacije o aktivnostima djece s prijateljima, njihovim odnosima s vršnjacima i negativnim karakteristikama vršnjaka nego što im to djeca priznaju, dok razlika između prosječnih procjena majki i adolescenata o pravu roditelja na poznavanje pozitivnih karakteristika vršnjaka nije statistički značajna. Razlike između stavova djece i roditelja na skalama Upitnika roditeljskog prava na informacije o djeci provjeravane su samo u jednom kvalitativnom istraživanju koje je uključilo mali broj sudionika različite etničke pripadnosti. U ovom uzorku roditelji su, u odnosu na adolescente, smatrali da imaju značajno veće pravo na informacije o djeci u svim područjima (Brown i sur., 2007). Poznavanje pozitivnih karakteri- 
stika vršnjaka područje je gdje majke ocjenjuju svoje pravo na informacije o djeci najmanjim, vjerojatno stoga što ih više brinu svakodnevne aktivnosti djece koje bi mogle utjecati na njihovu sigurnost i dobrobit. Interkorelacije skala Upitnika roditeljskog prava na informacije o djeci u uzorku majki i u uzorku adolescenata ukazuju na to da se njihova percepcija legitimnosti roditeljskog autoriteta u području pozitivnih karakteristika vršnjaka donekle razlikuje u odnosu na ostale domene vršnjačkih odnosa adolescenata. Iako su u oba uzorka dobivene značajne pozitivne korelacije u ocjeni legitimnosti roditeljskog autoriteta u svim domenama, najmanje interkorelacije dobivene su između pozitivnih karakteristika vršnjaka i ostalih subskala. Najveće značajne razlike u stavovima adolescenata i majki dobivene su u procjeni roditeljske nadležnosti u domeni negativnih karakteristika vršnjaka. $\mathrm{Na}$ neslaganje djece i roditelja u ovom području upućuju i korelacije između stavova adolescenata i njihovih majki o tome što roditelji imaju pravo znati o djeci. Korelacija između procjena majki i djece o roditeljskom pravu na informacije o negativnim karakteristikama vršnjaka nije značajna, dok su stavovi majki i djece u odnosu na legitimnost roditeljskog autoriteta u ostale tri domene značajno pozitivno povezani. Valja napomenuti da se i u ovom slučaju ne radi o visokom slaganju, jer su dobivene korelacije niske do umjerene.

Rezultati našeg istraživanja u skladu su s istraživanjima u okviru teorije socijalnih domena koja pokazuju da roditelji općenito svoj legitimitet nad različitim područjima života adolescenata procjenjuju većim nego što to čine sami adolescenti (Smetana i Asquith, 2004; Smetana i sur., 2006). Ova istraživanja također pokazuju da roditelji i adolescenti smatraju roditeljsku nadležnost legitimnom kada se radi o pitanjima razboritosti (sigurnosti), a više se razlikuju u određivanju granica roditeljskog autoriteta kada se radi o višefacetnim pitanjima koja, uz ostalo, uključuju aktivnosti i odnose s vršnjacima (npr. druženje s prijateljima koje roditelji ne odobravaju ili izlasci s djevojkom/mladićem). Roditelji uglavnom gledaju na takve probleme kao na konvencionalno regulirane ili pitanja sigurnosti djece, dok adolescenti često na takve probleme gledaju kao na svoje osobno područje (Nucci, 2001; Nucci, Smetana, Araki, Najau i Comer, 2014; Smetana i sur., 2006). U našem istraživanju ispitivani su stavovi djece i roditelja o pravu roditelja na informacije o rizičnim ponašanjima prijatelja i skupine vršnjaka kojoj adolescenti pripadaju. Može se pretpostaviti da roditelji ovo područje smatraju pitanjem sigurnosti djece, dok ga adolescenti definiraju kao osobno pitanje. Rezultati kvalitativnih istraživanja u kojima su analizirani odgovori adolescenata na pitanja o tome zbog čega bi roditelji trebali imati pravo znati o aktivnostima i odnosima djece s vršnjacima omogućuju bolji uvid u dobivene rezultate (Brown i sur., 2007; Krein, 2003). Adolescenti su priznavali roditeljima veću nadležnost u području aktivnosti s prijateljima jer su smatrali da su roditelji odgovorni za sigurnost djece te trebaju znati gdje su i s kime djeca. S druge strane, navodili su kako bi bili manje voljni otkriti informacije o značajkama njihovih odnosa s prijateljima i romantičnim partnerima jer je to područje osobne prirode. Adolescenti su smatrali da je dobro roditeljima prenositi informacije o pozi- 
tivnim karakteristikama vršnjaka kako bi zadobili njihovo povjerenje, pogotovo ako žele izlaziti van. Prema njihovu mišljenju, roditelji ne bi trebali puno znati o rizičnim ponašanjima vršnjaka, a kao razloge češće su navodili strah od negativnih posljedica i brigu da će izgubiti povjerenje roditelja nego osoban izbor. Slične rezultate pokazuju istraživanja o samootkrivanju adolescenata $u$ domeni razboritosti (sigurnosti), koja uključuje njihova rizična ponašanja. Iako u ovom području adolescenti priznaju legitimnost roditeljskog autoriteta, oni su manje skloni otkrivati roditeljima informacije o vlastitom rizičnom ponašanju nego o osobnim pitanjima. Kao razlog prešućivanja informacija u domeni sigurnosti adolescenti navode zabrinutost da roditelji to neće odobravati, a manje otkrivaju informacije iz osobne domene jer smatraju da je to njihova privatna stvar i da takve aktivnosti nikome ne štete (Nucci i sur., 2014; Smetana i sur. 2006). U jednom novijem istraživanju majke adolescenata pitalo se koliko žele znati o aktivnostima djece u raznim područjima društvenog života. Majke su najviše željele saznati o pitanjima sigurnosti koja se odnose na rizična ponašanja djece kada su izvan kuće, značajno manje o višefacetnim pitanjima koja uključuju dječje interakcije s vršnjacima i izlaske s romantičnim partnerima/ icama, a najmanje (iako još uvijek u velikoj mjeri) o osobnim svakodnevnim pitanjima koja uključuju privatnost adolescenata (Smetana i Rote, 2015). Uzimajući u obzir rezultate navedenih istraživanja, bilo bi važno istražiti kako su neslaganja u stavovima između majki i djece o nadležnosti roditelja u domeni koja se odnosi na rizična ponašanja vršnjaka povezana s ponašanjem adolescenata i odnosima između djece i roditelja. Značajne razlike u stavovima majki i djece pokazuju kako majke imaju pogrešno uvjerenje da je njihov autoritet u domeni negativnih karakteristika vršnjaka veći, dok im djeca priznaju malu nadležnost u ovom području. Istraživanja pokazuju da adolescenti koji se problematično ponašaju više skrivaju informacije o svom rizičnom ponašanju od roditelja (Smetana i sur, 2006). Zato roditelji trebaju stvoriti emocionalnu klimu u obitelji koja potiče samootkrivanje djece (iniciranje razgovora te podrška i uvažavajuće vodstvo nakon samootkrivanja), a također roditeljima omogućuje da traže informacije kada je to potrebno a da djeca ne smatraju da su pod prisilom (Pećnik i Tokić, 2011).

Sljedeći korak u analizi rezultata bio je ispitati spolne razlike u stavovima adolescenata prema roditeljskom pravu na informacije o njihovim aktivnostima i odnosima s vršnjacima. Multivarijatna analiza varijance s četiri mjere stavova adolescenata kao zavisnim varijablama i njihovim spolom i razredom koji pohađaju kao nezavisnim varijablama pokazala je značajne glavne efekte spola i dobi adolescenata, dok interakcija spola i dobi nije bila značajna. Jednostavnim analizama varijance utvrđeni su značajni efekti spola u svim domenama stavova adolescenata, osim u odnosu na pozitivne karakteristike vršnjaka. Djevojke, u odnosu na mladiće, statistički značajno pozitivnije procjenjuju roditeljsko pravo na informacije o njihovim aktivnostima s prijateljima, značajkama odnosa s vršnjacima i negativnim karakteristikama vršnjaka. Efekt dobi pokazao se značajnim samo na varijabli značajki odnosa s vršnjacima, pri čemu stariji učenici priznaju veću nadležnost 
roditeljima u ovom području. Međutim, dobne razlike u ovom slučaju nisu velike te uz stroži kriterij značajnosti (Bonfferonijeva korekciju) koji smo upotrebljavali zbog višestrukih usporedbi ova razlika nije značajna. Multivarijatna analiza varijance rezultata majki na skalama Upitnika roditeljskog prava na informacije o djeci u odnosu na spol i dob djeteta dala je slične rezultate. Dobiven je značajan efekt spola djeteta, dok efekti dobi djeteta te interakcije spola i dobi nisu bili značajni. Rezultati jednostavnih analiza varijance pokazali su kako majke koje imaju kćer, u odnosu na majke sinova, smatraju da roditelji trebaju više znati o aktivnostima djece s prijateljima i značajkama njihovih odnosa s vršnjacima. Rezultati našeg istraživanja koji pokazuju značajan efekt spola na stavove adolescenata, pri čemu djevojke priznaju roditeljima veću nadležnost u tri domene vršnjačkih odnosa, razlikuju se $\mathrm{u}$ odnosu na rezultate dvaju istraživanja s američkim adolescentima u kojima nisu dobivene spolne razlike na skalama Upitnika roditeljskog prava na informacije o djeci (Chan i sur., 2015; Krein, 2003). U tim istraživanjima dobiveni su nedosljedni rezultati u odnosu na dobne razlike u stavovima adolescenata. U istraživanju koji je provela Krein (2003) u uzorku adolescenata prosječne dobi od 14 i pol godina, značajan efekt dobi pokazao se samo za negativne karakteristike vršnjaka, pri čemu adolescenti priznaju roditeljima manje pravo na informacije u ovom području što su stariji. Međutim, višestruke usporedbe pokazale su da su razlike bile značajne samo između učenika sedmih razreda i srednjoškolaca, dok razlike između mlađih i starijih srednjoškolaca nisu bile značajne. Ovi rezultati u skladu su s rezultatima našeg istraživanja koje je uključilo samo učenike prvih, drugih i trećih razreda srednje škole. Chan i sur. (2015) primijenili su skraćenu verziju od 19 čestica Upitnika roditeljskog prava na informacije o djeci i utvrdili su trend smanjenja priznanja roditeljske nadležnosti s dobi za sve subskale, osim za značajke odnosa s vršnjacima. U odnosu na naše istraživanje, ovo istraživanje uključilo je mlađu djecu prosječne dobi od 13 godina (učenike šestih i osmih razreda te drugih razreda srednje škole). U budućim istraživanjima bilo bi korisno obuhvatiti širi raspon dobi adolescenata kako bi se dobne razlike u njihovim stavovima o roditeljskom pravu na informacije o djeci ispitale s obzirom na razvojne promjene u odnosima s vršnjacima u ranoj, srednjoj i kasnoj adolescenciji. U dosadašnjim istraživanjima ovaj instrument primijenjen je na prigodnim uzorcima adolescenata, a razlike u stavovima roditelja i djece u odnosu na spol djece nisu provjeravane. Budući da je općenito malo istraživanja o stavovima adolescenata i roditelja u odnosu na roditeljsko pravo na informacije o vršnjačkim odnosima djece, u objašnjenu dobivenih spolnih razlika navodimo rezultate koji se odnose na povezane procese, tj. na roditeljsko znanje, kvalitetu komunikacije između djece i roditelja i adolescentsko samootkrivanje.

Majke općenito znaju više o djeci od očeva, a majke i očevi iz istih obitelji znaju više o aktivnostima djece istog spola. Ove razlike mogu se dijelom objasniti socijalizacijom uloga roditelja raznog spola, gdje se od majki očekuje da znaju više o aktivnostima svoje djece, a roditelji ujedno dijele interese i provode više vremena u zajedničkim aktivnostima s djecom istog spola (Crouter, Helms-Erikson, Upde- 
graff i McHale, 1999). Istraživanja su pokazala da djevojke više otkrivaju majkama informacije o osobnim pitanjima (Smetana i sur., 2006), brigama i osjećajima te dnevnim aktivnostima nego mladići (Pećnik i Tokić, 2001). Djevojke također očekuju da će kasnije postići autonomiju nego mladići, a postoje i kulturalne razlike s obzirom na dob kada mladi očekuju postizanje autonomije. U kolektivističkim kulturama koje više vrednuju tradiciju, prosocijalna ponašanja i dobro socijalizirano ponašanje mladih mladi očekuju da će postići kasniju bihevioralnu autonomiju nego u kulturama koje u većoj mjeri ističu individualizam, uspješnost i natjecanje (Feldman i Rosenthal, 1991). U istraživanju s reprezentativnim uzorkom hrvatskih srednjoškolaca utvrđeno je da se mladići više rizično ponašaju, a, prema procjenama učenika, roditelji ohrabruju u većoj mjeri neovisnost sinova nego kćeri i više znaju o aktivnostima ženske nego muške djece (Raboteg-Šarić, Sakoman i Brajša-Žganec, 2002). U skladu s time su i rezultati Daddisa i Smetane (2005) prema kojima djeca i roditelji očekuju da će mladići ranije postići autonomiju u domeni razboritosti (rizična ponašanja) nego djevojke.

Rezultati našeg istraživanja pokazali su kako se stavovi adolescenata i njihovih majki u odnosu na legitimnost roditeljskog autoriteta u specifičnim područjima dječjih vršnjačkih odnosa (aktivnosti s prijateljima, značajke odnosa s vršnjacima i negativne karakteristike vršnjaka) značajno razlikuju, pri čemu majke smatraju da imaju veće pravo na znanje o djeci nego što su im djeca spremna priznati. Pritom majke djece ženskog spola, u odnosu na majke djece muškog spola, pridaju roditeljima veće pravo na znanje o aktivnostima njihovih kćeri s prijateljima i odnosima djece s vršnjacima. I same djevojke, u odnosu na mladiće, imaju pozitivnije stavove prema legitimnosti roditeljskog autoriteta u navedenim područjima, a također i u odnosu na negativne karakteristike vršnjaka. Prethodno opisana istraživanja s roditeljima različitog spola općenito pokazuju kako su majke više uključene u odgoj djece. Stoga smo u ovom istraživanju, iz praktičnih razloga, uključili samo majke. Glavni nedostatak našeg istraživanja je neuključivanje očeva kao sudionika istraživanja. Nadalje, potrebno je napomenuti kako su adolescenti ispunjavali upitnik u odnosu na roditelje, a u istraživanju ih se uspoređivalo samo s majkama. U daljnjim istraživanjima trebalo bi stoga provjeriti razlikuju li se adolescenti i roditelji u tome koliku nadležnost priznaju majci i ocu u različitim domenama vršnjačkih odnosa djece. Ove pretpostavke potrebno je provjeriti i kvalitativnim metodama radi boljeg uvida $u$ razloge pojedinih stavova roditelja i samih adolescenata. Razumijevanje razlika u stavovima roditelja i djece različitog spola i razloga koje navode za svoja uvjerenja omogućilo bi bolji uvid u svakodnevnu komunikaciju između adolescenata i njihovih roditelja i proces uspostave ponašajne autonomije $\mathrm{u}$ adolescenciji. 


\section{LITERATURA}

Bakken, J. P. i Brown, B. B. (2010). Adolescent secretive behavior: African American and Hmong adolescents' strategies and justifications for managing parents' knowledge about peers. Journal of Research on Adolescence, 20(2), 359-388. DOI: 10.1111/j.15327795.2010.00642.x

Brown, B. B., Bakken, J. P., Nguyen, J. i Von Bank, H. (2007). Sharing information about peer relations: Parent and adolescent opinions and behaviors in Hmong and African American families. U B. B. Brown i N. S. Mounts (Ur.), Linking parents and family to adolescent peer relations: Ethnic and cultural considerations (str. 67-82). San Francisco: Jossey-Bass.

Brown, B. B., Mounts, N., Lamborn, S. D. i Steinberg, L. (1993). Parenting practices and peer group affiliation in adolescence. Child Development, 64(2), 467-482. DOI: 10.1111/j.1467-8624.1993.tb02922.x

Chan, H. Y., Brown, B. B. i Von Bank, H. (2015). Adolescent disclosure of information about peers: The mediating role of perceptions of parents' right to know. Journal of Youth and Adolescence, 44(5), 1048-1065. DOI: 10.1007/s10964-015-0261-9

Crouter, A. C., Helms-Erikson, H., Updegraff, K. i McHale, S. M. (1999). Conditions underlying parents' knowledge about children's daily lives in middle childhood: Between- and within-family comparisons. Child Development, 70(1), 246-259. DOI: 10.1111/1467-8624.00018

Daddis, C. i Smetana, J. (2005). Middle-class African American families' expectations for adolescents' behavioral autonomy. International Journal of Behavioral Development, 29(5), 371-381. DOI: 10.1080/01650250500167053

Darling, N., Cumsille, P., Caldwell, L. L. i Dowdy, B. (2006). Predictors of adolescents' disclosure to parents and perceived parental knowledge: Between- and within-person differences. Journal of Youth and Adolescence, 35(4), 667-678. DOI: 10.1007/s10964006-9058-1

Feldman, S. S. i Rosenthal, D. A. (1991). Age expectations of behavioral autonomy in Hong Kong, Australian and American Youth: The influence of family variables and adolescents' values. International Journal of Psychology, 26(1), 1-23. DOI: $10.1080 / 00207599108246846$

Finkenauer, C., Frijns, T., Engels, R. C. M. E. i Kerkhof, P. (2005). Perceiving concealment in relationships between parents and adolescents: Links with parental behavior. Personal Relationships, 12(3), 387-406. DOI: 10.1111/j.1475-6811.2005.00122.x

Goossens, L. (2006). The many faces of adolescent autonomy: Parent-adolescent conflict, behavioral decision-making, and emotional distancing. U S. Jackson i L. Goossens (Ur.), Handbook of adolescent development (str. 135-153). Hove, UK: Psychology Press.

Grotevant H. D. i Cooper, C. R. (1998). Individuality and connectedness in adolescent development: Review and prospects for research on identity, relationships, and context. U E. Skoe i A. von der Lippe (Ur.), Personality development in adolescence: A cross national and life span perspective (str. 3-36). London: Routledge.

Hartup, W. W. i Stevens, N. (1997). Friendships and adaptation in the life course. Psychological Bulletin, 121(3), 355-370. DOI: 10.1037/0033-2909.121.3.355 
Krein, H. (2003). Information about peers: What adolescents think parents have the right to know. Master of Science Thesis, University of Wisconsin-Madison.

Krein, H. i Brown, B. B. (2004). Assessing what adolescents think parents have the right to know: The right to know scale. Rad je prezentiran na konferenciji The Biennial Meeting of the Society for Research on Adolescence, Baltimore, Maryland.

Lacković-Grgin, K., Penezić, Z. i Žutelija, S. (2001). Dobne i spolne razlike u samootkrivanju adolescenata različitim osobama. Društvena istraživanja, 10(3), 341-363.

Larson, R. W., Richards, M. H., Moneta, G., Holmbeck, G. i Duckett, E. (1996). Changes in adolescents' daily interactions with their families from ages 10 to 18: Disengagement and transformation. Developmental Psychology, 32(4), 744-754. DOI: 10.1037/00121649.32.4.744

Nucci, L. (2001). Education in the moral domain. Cambridge: Cambridge University Press.

Nucci, L., Smetana, J., Araki, N., Najau, M. i Comer, J. (2014). Japanese adolescents' disclosure and information management with parents. Child Development, 85(3), 901-907. DOI: $10.1111 /$ cdev.12174

Pećnik, N. i Tokić, A. (2011). Roditelji i djeca na pragu adolescencije: pogled iz tri kuta, izazovi i podrška. Zagreb: Ministarstvo obitelji, branitelja i međugeneracijske solidarnosti.

Raboteg-Šarić, Z., Franc, R. i Brajša-Žganec, A. (2004). Roditeljski odgojni postupci i psihosocijalni razvoj adolescenata. U Lj. Kaliterna Lipovčan i V. Šakić (Ur.), Hrvatsko društvo danas: psihosocijalni procesi (str. 59-76). Zagreb: Institut društvenih znanosti Ivo Pilar.

Raboteg-Šarić, Z., Sakoman, S. i Brajša-Žganec, A. (2002). Stilovi roditeljskog odgoja, slobodno vrijeme i rizično ponašanje mladih. Društvena istraživanja, 11(2-3), 239-263.

Smetana, J. G. iAsquith, P. (1994). Adolescents' and parents' conceptions of parental authority and personal autonomy. Child Development, 65(4), 1147-1162. DOI: 10.2307/1131311

Smetana, J.G. i Metzger, A. (2008). Don’t ask, don’t tell (your mom and dad): Disclosure and nondisclosure in adolescent-parent relationships. U M. Kerr, H. Stattin, i R.C.M.E. Engels (Ur.), What can parents do?: New insights into the role of parents in adolescent problem behaviour (str.65-87). Chichester, UK: John Wiley \& Sons.

Smetana, J. G., Metzger, A., Gettman, D. C. i Campione-Barr, N. (2006). Disclosure and secrecy in adolescent-parent relationships. Child Development, 77(1), 201-217. DOI: 10.1111/j.1467-8624.2006.00865.x

Smetana, J. G. i Rote, W. M. (2015). What do mothers want to know about teens' activities? Levels, trajectories, and correlates. Journal of Adolescence, 38, 5-15. DOI: 10.1016/j. adolescence.2014.10.006

Stattin, H. i Kerr, M. (2000). Parental monitoring: A reinterpretation. Child Development, 71(4), 1072-1085. DOI: 10.1111/1467-8624.00210

Stattin, H., Kerr, M. i Tilton-Weaver, L. (2010). Parental monitoring: A critical examination of the research. U V. Guilamo-Ramos, J. Jaccard i P. Dittus (Ur.), Parental monitoring of adolescents. Current perspectives for researchers and practitioners (str. 3-38). New York: Columbia University Press.

Tokić, A. (2008). Suvremene spoznaje u istraživanju povezanosti roditeljstva i adolescentske prilagodbe. Društvena istraživanja, 17(6), 1135-1155. 


\title{
WHAT PARENTS HAVE THE RIGHT TO KNOW ABOUT THEIR CHILDREN'S PEER RELATIONS - THE OPINIONS OF ADOLESCENTS AND THEIR MOTHERS
}

\begin{abstract}
The aim of the study was to examine the attitudes of adolescents and their mothers on what parents have the right to know about their children and the differences in the attitudes of parents and children with regard to adolescents' gender and age. The sample included 188 high school students (94 girls and 94 boys) with an average age of 16.6 years and their mothers $(\mathrm{N}=188)$. The Croatian version of the Right to Know Inventory (Krein and Brown, 2004) was used to measure attitudes toward the legitimacy of parental authority over four domains of adolescent peer relations: activities with friends, features of relationships, negative peer characteristics and positive peer characteristics. The results showed that mothers generally rate their right to know about their children and their children's activities higher than adolescents do. Significant differences were obtained between mothers' and children's scores on all scales of the Right to Know Inventory, except for positive peer characteristics. Multivariate analyses of variance revealed a significant effect of adolescent gender on their attitudes on parental right to information about children, as well as a significant effect of child gender on maternal attitudes. In both analyses, the effects of child age and interactions of gender and age were not significant. Girls, compared to boys, rate parental right to information about children significantly higher in all domains, except for positive peer characteristics. Mothers who have a daughter find themselves significantly more entitled to information about the activities of children with friends and the characteristics of their relationships with peers than mothers of sons. The results are discussed in relation to research on the legitimacy of parental authority in different social domains and research on adolescent self-disclosure.
\end{abstract}

Key words: adolescents, autonomy, peer relations, parental right to know

Primljeno: 13. 12. 2019. 